University of Nebraska - Lincoln

DigitalCommons@University of Nebraska - Lincoln

USDA Forest Service / UNL Faculty Publications U.S. Department of Agriculture: Forest Service --

National Agroforestry Center

2006

Survey of phytophagous insects and foliar pathogens in China for a biocontrol perspective on kudzu, Pueraria montana var. lobata (Willd.) Maesen and S. Almeida (Fabaceae)

\author{
Jiang-Hua Sun \\ Chinese Academy of Sciences \\ Zhu-Dong Liu \\ Chinese Academy of Sciences \\ Kerry O. Britton \\ USDA Forest Service Southern Research Station \\ Ping Cai \\ Anhui Agricultural University \\ David Orr \\ North Carolina State University \\ See next page for additional authors \\ Follow this and additional works at: https://digitalcommons.unl.edu/usdafsfacpub \\ Part of the Forest Sciences Commons
}

Sun, Jiang-Hua; Liu, Zhu-Dong; Britton, Kerry O.; Cai, Ping; Orr, David; and Hough-Goldstein, Judith, "Survey of phytophagous insects and foliar pathogens in China for a biocontrol perspective on kudzu, Pueraria montana var. lobata (Willd.) Maesen and S. Almeida (Fabaceae)" (2006). USDA Forest Service / UNL Faculty Publications. 85.

https://digitalcommons.unl.edu/usdafsfacpub/85

This Article is brought to you for free and open access by the U.S. Department of Agriculture: Forest Service -National Agroforestry Center at DigitalCommons@University of Nebraska - Lincoln. It has been accepted for inclusion in USDA Forest Service / UNL Faculty Publications by an authorized administrator of DigitalCommons@University of Nebraska - Lincoln. 


\section{Authors}

Jiang-Hua Sun, Zhu-Dong Liu, Kerry O. Britton, Ping Cai, David Orr, and Judith Hough-Goldstein 


\title{
Survey of phytophagous insects and foliar pathogens in China for a biocontrol perspective on kudzu, Pueraria montana var. lobata (Willd.) Maesen and S. Almeida (Fabaceae)
}

\author{
Jiang-Hua Sun ${ }^{\text {a }}$, Zhu-Dong Liu ${ }^{\text {a }}$, Kerry O. Britton ${ }^{\mathrm{b}}$, Ping Cai ${ }^{\mathrm{c}}$, David Orr ${ }^{\mathrm{d}}$, \\ Judith Hough-Goldstein ${ }^{\mathrm{e}, *}$ \\ ${ }^{a}$ State Key Laboratory of Integrated Management of Pest Insects and Rodents, Institute of Zoology, Chinese Academy of Sciences, Beijing 100080, China \\ ${ }^{\mathrm{b}}$ USDA Forest Service Southern Research Station, Athens, GA 30602-2044, USA \\ ${ }^{\mathrm{c}}$ Department of Plant Protection, Anhui Agricultural University, Hefei, Anhui Province, China \\ ${ }^{\mathrm{d}}$ Department of Entomology, North Carolina State University, Raleigh, NC 27695-7613, USA \\ ${ }^{\mathrm{e}}$ Department of Entomology and Wildlife Ecology, University of Delaware, Newark, DE 19716-2160, USA
}

Received 2 February 2005; accepted 16 September 2005

Available online 2 November 2005

\begin{abstract}
A three-year survey of kudzu foliage, seed, stems, and roots for associated phytophagous insects was conducted to establish basic information about the insect communities that kudzu harbors in China and to assess the abundance, diversity and damage caused by these insects. Diseases of kudzu were also surveyed in southern China. A total of 116 phytophagous insect species in 31 families and 5 orders were collected from kudzu in China, in six feeding guilds: foliage, sap, stem, terminal, seed and root feeders. The impact of foliage feeders varied from site to site and year to year, and over the course of the growing season. The mean percent defoliation of kudzu over all plots and years was $13.3 \pm 1.9 \%$, but ranged as high as $34 \%$. Two insect species fed on shoots and clipped off terminals. Infestation of new shoots was high, with nearly half of all shoots clipped. Nearly half of the vines showed damage from stem borers, again varying through the season. Two species of insects attacked kudzu roots, mainly the cerambycid beetle Paraleprodera diophthalma (Pascoe), which caused considerable damage to both small (young, $<3.4 \mathrm{~cm}$ diameter) and large (older, $>6 \mathrm{~cm}$ diameter) roots. Insects also caused substantial seed damage. Imitation rust, caused by Synchytrium minutum $[=S$. puerariae (P. Henning) Miyabe], was the most commonly observed disease of kudzu. Several of these species have potential as biological control agents for kudzu in the US.
\end{abstract}

(C) 2005 Elsevier Inc. All rights reserved.

Keywords: Feeding guilds; Biological control; Weeds; Invasive species

\section{Introduction}

Kudzu, Pueraria montana (Lour.) Merr. var. lobata (Willd.) Maesen and Almeida (Ward, 1998a), is an invasive exotic weed in the United States. A perennial, semi-woody, climbing leguminous vine, this species is of great concern in the southeastern United States (Forseth and Teramura, 1987; Holm et al., 1979; Patterson, 1976), but ranges from

\footnotetext{
* Corresponding author. Fax: +1 3028318889.

E-mail address: jhough@udel.edu (J. Hough-Goldstein).
}

Florida to Massachusetts and west to Oklahoma and Texas (Frankel, 1989; Mitich, 2000). New infestations have recently been reported in Oregon and Washington State (Washington State Noxious Weed Control Board, 2003).

Kudzu is native to and widely distributed in China except in the Xiangjiang Autonomous Region, Quinghai, and Tibet. Two other closely related varieties (generally considered species by Chinese botanists), $P$. montana var. montana and P. montana var. thomsonii (Ward, 1998b) are distributed mostly in the southern part of China. Kudzu can be found at elevations between 300 and $1500 \mathrm{~m}$ with the most common sites at low elevations including roadsides, 
tree plantations, clear-cut areas or any open land (Zhang and Wang, 1999). Kudzu is a short-daylight plant and grows well with precipitation of $1000-1500 \mathrm{~mm}$ on sand or clay soil. Its deep and well-developed root system enables kudzu to grow in very dry sites and in poor soil (Zhang and Ye, 1990). Shao (1993) estimated that kudzu is found on approximately 20 million ha in China. Although kudzu is widely distributed in China, there are no references to kudzu as a weedy pest problem there, probably because of suppressive factors such as herbivorous insects, and because the plant is economically important. In addition to its use in food preparation, brewing alcoholic beverages (Shao, 1993), and medicines (Yang et al., 1996), kudzu has been used in China for soil erosion control and soil improvement (N-fixation) (Yang et al., 1990; Zhang, 1987), livestock forage (Zhang, 1987; Zhang and Gu, 1998; Zhu, 1996), rope (authors' observations), and clothing in ancient times.

Kudzu was originally introduced into the United States as an ornamental vine in 1876 at the Philadelphia Centennial Exposition (Winberry and Jones, 1973), then as a forage crop at the beginning of the 20th century (Piper, 1920). A variety of studies have shown that kudzu is both high in quality and palatable to livestock (Corley et al., 1997; Duke, 1981; Ensminger and Olentine, 1978). However, widespread distribution of kudzu did not occur until the 1930s and '40s, when it was promoted by the USDA Soil Conservation Service for soil erosion control, especially in the Piedmont regions of Alabama, Georgia and Mississippi (Tabor and Susott, 1941). By 1953, kudzu was recognized as a weed and removed from the list of species recommended for use under the Agricultural Conservation Program. By 1970, it was listed as a common weed in the southeastern United States (Everest et al., 1999), and today is listed as a noxious weed in at least nine states. Estimates of the current kudzu infestation in the US vary considerably, from several hundred thousand to over 10 million acres (4.05 million ha), but the most commonly cited figure is around 7 million acres (2.84 million ha) (Britton et al., 2002; Corley et al., 1997; Everest et al., 1999; Fears and Frederick, 1977; Miller and Edwards, 1983; Mitich, 2000) and the infestation continues to spread. Kudzu is widely believed to drastically reduce biodiversity because of its ability to smother other vegetation and develop large-scale monocultures (Alderman, 1998), although quantitative investigations are lacking (Forseth and Innis, 2004). Matlock (2002) reported expert consensus in Mississippi that kudzu posed one of the most serious threats to natural areas due to its ability to overwhelm natural vegetation.

Various management and eradication programs have been explored to control the spread of kudzu in the US, including intensive herbicide application (Harrington et al., 2003; Miller, 1996; Miller and Edwards, 1983), livestock grazing (Bonsi et al., 1992), industrial use of the plant (Tanner et al., 1979), and use of the plant pathogen Pseudomonas syringae pv. phaseolicola (Britton et al., 2002). Although modern herbicides effectively kill kudzu (Harrington et al.,
2003; Thomas, 2000), substantial and sustained effort is required, because anything short of complete eradication will allow rapid reinfestation (Mississippi State University, 2001).

Biological control of kudzu has only recently been considered as a possible management strategy. Kudzu appears to be a good candidate for classical biological control, since this naturalized weed lacks natural enemies capable of lowering its pest status in the US (Thornton, 2004), but appears to have a rich complex of natural enemies in Asia (Britton et al., 2002; Pemberton, 1996).

Despite its important exotic weed status, little is known about insects feeding on kudzu in its native range. Studies in China have generally focused on how to utilize this species and on its growth and ecology (An et al., 1994; Chen and Zhang, 1985; Keung and Vallee, 1998; Shao, 1993; Yang et al., 1996; Zhang, 1987; Zhang and Ye, 1990). Tayutivutikul and Kusigemati (1992) provided a list of insects associated with kudzu in Japan, and Tayutivutikul and Yano $(1989,1990)$ studied the biology of two kudzu-feeding insects, Chauliops fallax (Hemiptera: Lygaeidae) and Megacopta punctissimum (Hemiptera: Plataspidae). In addition, six fungal diseases of kudzu have been reported, mostly in China (Britton et al., 2002; Zidak and Backman, 1996). Pemberton (1996) reported an abundance of natural enemies of kudzu in China and elsewhere in Asia, and noted that good potential exists for biological control of kudzu in the US. Other scientists who visited China agreed and encouraged the initiation of a biological control research program. Therefore, a cooperative program funded by the USDA Forest Service was initiated in 1999 to survey the natural enemies of kudzu in China, with a final goal of finding potential biocontrol agents for kudzu in the US. Here we report results of a three-year survey of insects on kudzu foliage, seed, stems, and roots, with the aim of establishing basic information about insect communities on kudzu in China and identifying species that may have potential as biological control agents in the US. Preliminary information on impacts of different feeding guilds on kudzu in China is also reported. In addition, we report results of a survey of diseases of kudzu in southern China.

\section{Materials and methods}

\subsection{Survey sites}

Surveys focused on three sites in Anhui Province, China, because a computer software climate-matching program (Climex, Hearne Scientific Software, Melbourne, Australia) indicated that this was the province most similar in climate to Atlanta, Georgia. One site was in Qianshan (coordinates $116.55,30.74$, elevation approximately $150 \mathrm{~m}$ ), south of the Yangtze River, which distinctly delineates flora and fauna in China. A second site was in Xuancheng $(118.79,30.88$, elevation approximately $400 \mathrm{~m}$ ), north of the Yangtze River, and another in Jinzhai (115.84, 31.47, elevation approximately $450 \mathrm{~m}$ ), located deep in the Dabieshan 
Mountains. The latter two sites were surrounded by pine plantations. All Anhui sites were in mountainous regions, where most kudzu in China occurs because of intensive farming in lowland areas. A fourth survey site was established in Guangdong Province, which is much further south and warmer than the Anhui mountain sites. This site (Longyandong, coordinates 113.32, 23.22, elevation approximately $50 \mathrm{~m}$ ) was located in agricultural land mixed with pine plantations.

\subsection{Systematic sampling}

At each site, five root crowns of kudzu were randomly selected for sampling, marked with stakes and surrounded by a circle of colored tape and a sign to prevent human disturbance and for ease of relocation. At each sample date, the surveyor followed the same path to avoid trampling and damaging vines draped along the ground. The Qianshan site was surveyed for 3 years (1999-2001), Xuancheng and Guangdong for 2 years (1999-2000), and the Jinzhai site for one year (1999). At all sites, surveys were conducted at 10-20 day intervals from May to November. Usually 4$5 \mathrm{~h}$ were spent at each site, but sometimes an entire day and night were spent to observe insects that fed at night. Collection of kudzu-feeding insects was conducted by hand-picking, aspirating from kudzu plants, sweep-netting, and in some cases caging and rearing. When immature insects were found, they were collected in a plastic bag together with the plant part on which they were feeding and taken back to the laboratory at the Department of Entomology, Anhui Agricultural University, for rearing to the adult stage and further species identification.

Most of the insect species were identified by Professor Cai Ping (Anhui Agricultural University). Some Chrysomelidae were identified by Professor Yang Xingke (Institute of Zoology, Chinese Academy of Sciences [CAS]), some Cerambycidae were identified by Professor Sun Jianghua, and some Hymenoptera were identified by Professor Yuan Decheng (Institute of Zoology, CAS). References used were Economic Insect Fauna of China, edited by the Editorial Committee of Fauna Sinica, Academia Sinica (Ge, 1966; Ge et al., 1984; Jinag et al., 1985; Liu, 1963; Liu and Bai, 1977; Pu, 1980; Tan et al., 1985; Yu et al., 1996; Zhang, 1985, 1995; Zhao and Chen, 1980). Host range information, where known, was obtained from these same references.

\subsection{Foliage damage}

Defoliation and defoliators were recorded using a $30 \times 30 \mathrm{~cm}$ quadrat sampler, hand catching, and net collection, plus sweep-netting over the kudzu. On the first two sample dates each year, defoliation was estimated by averaging defoliation for all leaves on all stems from each root crown, while on the remaining sample dates, defoliation was estimated by using the quadrat sampler, randomly selecting three locations in three different directions from each root crown. Five root crowns were sampled at each site. At each location, we placed the quadrat sampler over kudzu leaves and estimated the average defoliation of all leaves within the boundary of the quadrat by comparing them with a prepared pictorial graph. Only leaves that were more than $50 \%$ inside the quadrat boundaries were included. Between 5 and 25 leaves were included in each $30 \times 30 \mathrm{~cm}$ sample.

\subsection{Terminal damage}

For each root crown, three side branches were randomly selected, and all terminals on those branches were checked for signs of insect feeding damage such as clipping. Any insects feeding on these terminals were collected.

\subsection{Stem damage}

On the first two sample dates each year, stem damage (signs of insect feeding within stems, oviposition, etc.) was recorded on all vines from each root crown. On the remaining sampling dates, we estimated damage by randomly selecting one vine from each root crown. For each vine, damage on the main stem and on three branches spaced equidistant along the main stem was recorded. Damage was described and we noted whether the vine was dead above the area of damage. For each type of stem-borer damage that was observed, a cage was placed around the vine until the adult emerged, and adults were collected for identification.

\subsection{Root damage}

From December to March, 40-200 roots were dug in the sample plots and in randomly selected sites surrounding these plots to survey for root damage. Adult insects found in galleries in the roots were collected for identification, and larvae were returned to the laboratory with pieces of root for rearing to the adult stage. The diameter of each root and the diameters of insect tunnels found in the roots were measured and recorded.

\subsection{Seed damage}

An insect exclusion treatment consisting of a closed cage over a raceme was compared with an uncaged raceme to evaluate the impact of insect herbivory on kudzu seeds. For this trial, just before caging, older pods were removed while newly formed pods were retained and racemes were cut off just above the new pods to prevent further flowering. Cages were constructed of organdy $(64 \times 80$ threads per $\mathrm{cm}, 100 \%$ polyester $)$, sewn into sleeves $(25 \mathrm{~cm}$ long $\times 14 \mathrm{~cm}$ diameter $)$ with a $7-\mathrm{cm}$ opening through which racemes were inserted. The cages were tied at their bases with plastic-coated tie wire and labeled with aluminum tags. Six replicates were placed along a transect measuring approximately $75 \mathrm{~m}$ in Anhui Province in 2000. When seeds had reached maturity (about 8 
weeks), dried racemes were removed, placed in plastic bags, and taken back to the laboratory. The length of pods was measured and seeds were hulled from the pods and counted. Healthy, infested, and total numbers of seeds from each replicate were recorded. In addition, during mid to late October, we collected all seed pods from each of the five plants that had been sampled at each site. These seeds were X-rayed and those with damage were put in rearing containers, with some dissected for further observation. Numbers of healthy and infested seeds were recorded, and emerged adults were identified.

\subsection{Disease survey}

Diseased foliage was collected at the Guangdong site and at the Qianshan site in Anhui Province, when observed during systematic insect sampling. Seedlings were not surveyed for disease, nor was disease severity assessed. Foliage was collected into an ice chest and returned to the laboratory. Pathogens were identified by Dr. Zide Jiang, plant pathologist at South China Agricultural University, Guangzhou Province.

\subsection{Data analysis}

Data on foliar damage, root damage, pod length and seeds per pod were analyzed using one-way ANOVA after testing whether the data were normally distributed (SPSS Inc., 1999). Data on terminal clipping, stem damage and seed damage were analyzed using Chi-square tests (SAS Institute, 1998).

\section{Results}

\subsection{Insect diversity on kudzu}

A total of 116 phytophagous species in 31 families and 5 orders were collected from kudzu in Anhui and Guangdong Provinces from 1999 to 2000 (Table 1). Insects were found in six different feeding guilds: foliage, sap, stem, terminal, seed and root feeders (Table 2). Insect diversity in China was greater than that in the US, where only three feeding guilds of arthropods were found associated with kudzu, with no root, stem or terminal-feeding insects (Thornton, 2004; Table 2).

\subsection{Foliage-feeding insects}

Foliage-feeding insects from kudzu in China included 37 species from 15 families. The species that appeared to have the greatest impact on the plant were two chrysomelid beetles, Gonioctena tredecimmaculata (Jacoby) and Brachyphora nigrovittata Jacoby, and an argid sawfly, Arge sp. The extent of defoliation varied from site to site, from year to year, and over the course of the growing season. In Qianshan, Anhui Province, defoliation averaged 4-6\% in May each year, increasing to a peak of $12-18 \%$ in late June-early
July (Fig. 1A). Defoliation was higher in Xuancheng, averaging over $30 \%$ at some sample dates in June or July each year (Fig. 1B). Defoliation in the southern province, Guangdong, was surveyed for a longer period, and was highest early in the growing season (Fig. 2), averaging about $20 \%$ in 1999 and $10 \%$ in 2000 in June and generally declining over the season (Fig. 1C). The mean percent defoliation for kudzu per year among all plots and all years of study was $13.3 \pm 1.9 \%$.

\subsection{Terminal-clipping insects}

Two beetle species, Ornatalcides (Mesalcidodes) trifidus (Pascoe) (Coleoptera: Curculionidae) and Deporaus sp. (Coleoptera: Attelabidae), fed on shoots causing terminal death. Shoot clipping activity varied significantly over the season in both Xuancheng, Anhui Province $\left(\chi^{2}=78.4581\right.$, $P<0.0001, \quad N=692)$ and Guangdong $\left(\chi^{2}=72.5796\right.$, $P<0.0001, N=265)$ in 2000. In Xuancheng, new shoots were clipped at a relatively high rate $(\sim 20-40 \%)$ from June through October, while at Guangdong terminal clipping rose to a peak of about $90 \%$ of all new shoots clipped in mid- to late-August 2000 (Fig. 2).

\subsection{Stem insects}

Insects infesting kudzu stems were primarily the cerambycid species, Paraleprodera diophthalma (Pascoe), Atimura japonica Bates, and Pterolophia spp., and a buprestid species, Chalcophora japonica Gory. These insects either fed on phloem or bored into the stems causing vine death. Overall, nearly half of all vines were found to have stem damage, varying at different sites and over the season. In Qianshan, between 65 and $80 \%$ of all stems showed evidence of damage in 1999, while in 2001 stem damage ranged from 25 to $55 \%$ of stems (Fig. 3).

\subsection{Root insects}

Two species of insects were found attacking kudzu roots, the cerambycid species $P$. diophthalma and Aristobia hispida (Sanders). A total of 198, 48, and 44 roots were dug in Qianshan, Xuancheng, and Guangdong, respectively, and $31.5,62.5$, and $64.4 \%$ of these roots were infested by cerambycid larvae. The diameters of uninfested and infested kudzu roots and of insect tunnels in infested roots were measured in Qianshan and Guangdong. In Qianshan, healthy (uninfested) roots had an average diameter of $4.7 \mathrm{~cm}$, while insect-infested roots fell into two apparent categories, either significantly larger (mean of $6.7 \mathrm{~cm}$ diameter) or significantly smaller (mean of $3.3 \mathrm{~cm}$ diameter) than uninfested roots (Table 3A). Tunnel diameters were significantly larger in the large infested roots than in the small infested roots as well. In Guangdong, all of the roots collected were relatively small, and there was no significant difference in the root diameters of healthy and infested roots (Table 3B). 
Table 1

Phytophagous insects collected from kudzu in China, 1999-2001

\begin{tabular}{|c|c|c|c|c|c|}
\hline $\begin{array}{l}\text { Order }^{\mathrm{a}} \\
\text { Family }^{\mathrm{a}}\end{array}$ & Species & Freq $^{b}$ & Stage found ${ }^{\mathrm{c}}$ & Feeding guild & Host range ${ }^{\mathrm{d}}$ \\
\hline \multicolumn{6}{|l|}{ Orthoptera } \\
\hline \multirow[t]{2}{*}{ Acrididae } & Chondracris rosea (De Geer) & $\mathrm{R}$ & A & Foliage & Po \\
\hline & Paratonkinacris vittifemoralis You et Li & $\mathrm{R}$ & A & Foliage & Unknown \\
\hline Gryllidae & Oecanthus sinensis Walker & $\mathrm{R}$ & A & Foliage & $\mathrm{Po}$ \\
\hline \multicolumn{6}{|c|}{ Hemiptera (S.O. Heteroptera) } \\
\hline Berytidae & Yemma exilis Horvath & $\mathrm{R}$ & A & Sap & Unknown \\
\hline \multirow[t]{10}{*}{ Coreidae } & Acanthocoris scaber (L.) & $\mathrm{R}$ & A & Sap & Po \\
\hline & Anoplocnemis phasiana $(\mathrm{F})$. & $\mathrm{R}$ & A & Sap & Po \\
\hline & Cletus punctiger Dallas & $\mathrm{R}$ & A & Sap & Po \\
\hline & Cletus trigonus (Thunberg) & $\mathrm{R}$ & A & Sap & Unknown \\
\hline & Hygia opaca (Uhler) & $\mathrm{R}$ & A & Sap & Unknown \\
\hline & Homoeocerus marginellus Herrich-Schaeffer & $\mathrm{R}$ & A & Sap & Po \\
\hline & Liorhyssus hyalinus (F.) & $\mathrm{R}$ & A & Sap & Unknown \\
\hline & Mictis angusta $(\mathrm{Hsiao})$ & $\mathrm{R}$ & A & Sap & Po \\
\hline & Paraplesius unicolor Scott & $\mathrm{R}$ & A & Sap & Po \\
\hline & Riptortus pedestris $(\mathrm{F})$. & $\mathrm{R}$ & A & Sap & Unknown \\
\hline \multirow[t]{7}{*}{ Lygaeidae } & Chauliops bisontula Scott & $\mathrm{C}$ & $\mathrm{A}, \mathrm{N}$ & Sap & Po \\
\hline & Chauliops fallax $\mathrm{Scott}$ & $\mathrm{O}$ & A & Sap & Po \\
\hline & Macropes bambusiphilus Zheng & $\mathrm{R}$ & A & Sap & Unknown \\
\hline & Malcus elongatus Stys & $\mathrm{R}$ & A & Sap & $\mathrm{Po}$ \\
\hline & Malcus sinicus Stys & $\mathrm{R}$ & A & Sap & Po \\
\hline & Nysius ericae Schilling & $\mathrm{O}$ & A & Sap & Po \\
\hline & Tropidothorax elegans (Distant) & $\mathrm{R}$ & A & Sap & Po \\
\hline \multirow[t]{2}{*}{ Miridae } & Adelphocoris quadripunctatus (F.) & $\mathrm{R}$ & A & Sap & Po \\
\hline & Halticus tibialis Reuter & $\mathrm{R}$ & A & Sap & $\mathrm{Po}$ \\
\hline \multirow[t]{5}{*}{ Pentatomidae } & Aspongopus chinensis Dallas & $\mathrm{R}$ & $\mathrm{A}, \mathrm{N}$ & Sap & Unknown \\
\hline & Cyclopelta obscura (Lepeletier-Serville) & $\mathrm{R}$ & $\mathrm{A}, \mathrm{N}$ & Sap & Unknown \\
\hline & Halyomorpha halys (Stal) & $\mathrm{R}$ & $\mathrm{A}, \mathrm{N}$ & Sap & Unknown \\
\hline & Nezara viridula $(\mathrm{L})$. & $\mathrm{R}$ & A & Sap & Po \\
\hline & Palomena amplifioata Distant & $\mathrm{R}$ & A & Sap & Po \\
\hline \multirow[t]{5}{*}{ Plataspidae } & Cydnocoris russatus Stal & $\mathrm{R}$ & A & Sap & Po \\
\hline & Megacopta cribraria (Fabricius) & $\mathrm{C}$ & $\mathrm{A}, \mathrm{N}$ & Sap, Seed & Po \\
\hline & Megacopta distanti (Montandon) & $\mathrm{O}$ & A & Sap & Mo \\
\hline & Megacopta sp. & $\mathrm{R}$ & A & Sap, Seed & $\mathrm{Ol}$ \\
\hline & Pyrrhopeplus cardulis (Stal) & $\mathrm{R}$ & A & Sap & Po \\
\hline Pyrrhocoridae & Sclomina erinacea Stal & $\mathrm{R}$ & A & Sap & Po \\
\hline Urostylidae & Urostylis annulicornis $\mathrm{Scott}$ & $\mathrm{R}$ & A & Sap & Unknown \\
\hline \multicolumn{6}{|c|}{ Hemiptera (S.O. Auchenorrhyncha) } \\
\hline \multirow[t]{21}{*}{ Cicadellidae } & Aguriahana zheensis Cai et He & $\mathrm{R}$ & A & Sap & Mo \\
\hline & Amrasca biguttula (Ishida) & $\mathrm{R}$ & A & Sap & Po \\
\hline & Apheliona fenuginea (Matsumura) & $\mathrm{O}$ & A & Sap & $\mathrm{Ol}$ \\
\hline & Bothrogonia sinica Yang et $\mathrm{Li}$ & $\mathrm{R}$ & A & Sap & Po \\
\hline & Cicadella viridis (L.) & $\mathrm{R}$ & A & Sap & Po \\
\hline & Empoasca decedens Paoli & $\mathrm{R}$ & A & Sap & Mo \\
\hline & Exitianus indicus (Distant) & $\mathrm{R}$ & A & Sap & Unknown \\
\hline & Hishimonus sellaus (Uhler) & $\mathrm{R}$ & A & Sap & Unknown \\
\hline & Kolla paulula (Walker) & $\mathrm{R}$ & A & Sap & Po \\
\hline & Krisna nigromarginata Cai et Shen & $\mathrm{R}$ & A & Sap & $\mathrm{Ol}$ \\
\hline & Kutara nuchali Jacobi & $\mathrm{R}$ & A & Sap & Mo \\
\hline & Norva anufrievi Emeljanov & $\mathrm{R}$ & A & Sap & Unknown \\
\hline & Paivanana indra (Distant) & $\mathrm{R}$ & A & Sap & Unknown \\
\hline & Paralaevicephalus nigrifemoratus (Matsumura) & $\mathrm{R}$ & A & Sap & Mo \\
\hline & Paramesus mokanshanae Wilson & $\mathrm{R}$ & A & Sap & Unknown \\
\hline & Riseveinus sinensis (Jacobi) & $\mathrm{R}$ & A & Sap & Mo \\
\hline & Sophonia rubrolimbata (Kuoh et Kuoh) & $\mathrm{O}$ & A & Sap & Unknown \\
\hline & Sophonia rufolineata (Kuoh) & $\mathrm{R}$ & A & Sap & Mo \\
\hline & Tautoneura arachisi (Matsumura) & $\mathrm{C}$ & A & Sap & $\mathrm{Ol}$ \\
\hline & Tituria colorata Jacobi & $\mathrm{R}$ & A & Sap & Mo \\
\hline & Yanocephalus yanonis (Matsumura) & $\mathrm{R}$ & A & Sap & Po \\
\hline
\end{tabular}


Table 1 (continued)

\begin{tabular}{|c|c|c|c|c|c|}
\hline Order $^{\mathrm{a}}$ & Species & Freq $^{\mathrm{b}}$ & Stage found ${ }^{\mathrm{c}}$ & Feeding guild & Host range $^{d}$ \\
\hline \multicolumn{6}{|l|}{ Family $^{\mathrm{a}}$} \\
\hline Delphacidae & Sogatella furcifera (Horvath) & $\mathrm{R}$ & A & Sap & Unknown \\
\hline \multirow[t]{3}{*}{ Membracidae } & Gargara sp. & $\mathrm{R}$ & A & Sap & Po \\
\hline & Gargara genistae $(\mathrm{F})$. & $\mathrm{R}$ & A & Sap & Unknown \\
\hline & Tsunozemia mojiensis Matsumura & $\mathrm{R}$ & A & Sap & Unknown \\
\hline Fulgoridae & Lycorma delicatula White & $\mathrm{R}$ & A & Sap & Po \\
\hline \multirow[t]{2}{*}{ Ricaniidae } & Ricania speculum (Walker) & $\mathrm{R}$ & A & Sap & Po \\
\hline & Ricania taeniata Stal & $\mathrm{R}$ & A & Sap & Unknown \\
\hline \multicolumn{6}{|l|}{ Coleoptera } \\
\hline \multirow[t]{2}{*}{ Attelabidae } & Deporaus sp. & $\mathrm{C}$ & A & Terminal & Mo \\
\hline & Deporaus unicolor Rodofs & $\mathrm{C}$ & A & Terminal & Unknown \\
\hline Bostrychidae & Unknown & $\mathrm{R}$ & A & Stem & Unknown \\
\hline \multirow[t]{2}{*}{ Buprestidae } & Agrilus sp. & $\mathrm{C}$ & $\mathrm{A}, \mathrm{P}, \mathrm{L}$ & Foliage, Stem & Mo \\
\hline & Chalcophora japonica Gory & $\mathrm{R}$ & $\mathrm{L}$ & Stem & Unknown \\
\hline \multirow[t]{11}{*}{ Cerambycidae } & Aristobia hispida (Sunders) & $\mathrm{C}$ & $\mathrm{A}, \mathrm{L}$ & Root & Po \\
\hline & Atimura japonica Bates & $\mathrm{O}$ & $\mathrm{L}$ & Stem & Po \\
\hline & Mesosa irrorata Gressitt & $\mathrm{O}$ & $\mathrm{L}$ & Stem & Po \\
\hline & Oberea ferruginea Casey & $\mathrm{O}$ & $\mathrm{L}$ & Stem & Unknown \\
\hline & Paraleprodera diophthalma (Pascoe) & $\mathrm{O}$ & $\mathrm{L}, \mathrm{P}$ & Root, Stem & $\mathrm{Ol}$ \\
\hline & Phytoecia rufiventris Gautier & $\mathrm{R}$ & $\mathrm{L}$ & Stem & Po \\
\hline & Pterolophia annulata (Chevrolat) & $\mathrm{O}$ & $\mathrm{L}$ & Stem & Po \\
\hline & Pterolophia serricornis Gressitt & $\mathrm{O}$ & $\mathrm{L}$ & Stem & Po \\
\hline & Ropica sp. & $\mathrm{R}$ & $\mathrm{L}$ & Foliage & Unknown \\
\hline & Xenolea sp. & $\mathrm{O}$ & $\mathrm{L}$ & Stem & Unknown \\
\hline & Xylariopsis sp. & $\mathrm{O}$ & $\mathrm{L}$ & Stem & Po \\
\hline \multirow[t]{12}{*}{ Chrysomelidae } & Altica cyanea (Weder) & $\mathrm{R}$ & A & Foliage & Unknown \\
\hline & Borowiecius ademptus (Sharp) & $\mathrm{C}$ & $\mathrm{L}$ & Seed & Unknown \\
\hline & Brachyphora nigrovittata Jacoby & $\mathrm{C}$ & $\mathrm{A}, \mathrm{L}$ & Foliage & Po \\
\hline & Dactylispa angulosa (Solsky) & $\mathrm{R}$ & A & Foliage & Unknown \\
\hline & Colposcelis signata (Matschulsky) & $\mathrm{C}$ & $\mathrm{A}, \mathrm{L}$ & Foliage & Po \\
\hline & Dercetina sp. & $\mathrm{R}$ & A & Foliage & Po \\
\hline & Gonioctena tredecimmaculata (Jacoby) & $\mathrm{C}$ & $\mathrm{A}, \mathrm{L}$ & Foliage & Mo \\
\hline & Japonitata sp. & $\mathrm{R}$ & A & Foliage & Po \\
\hline & Melanotus sp. & $\mathrm{R}$ & A & Foliage & Unknown \\
\hline & Oides tarsatus (Olivier) & $\mathrm{R}$ & A & Foliage & Po \\
\hline & Sagra femorata purpurea Lichtenstein & $\mathrm{C}$ & A & Stem & Po \\
\hline & Smaragdina nigrifrons (Hope) & $\mathrm{R}$ & A & Foliage & Po \\
\hline Coccinellidae & Epilachna chinensis (Weise) & $\mathrm{R}$ & A & Foliage & Po \\
\hline \multirow[t]{7}{*}{ Curculionidae } & Curculio dieckmanni (Faust) & $\mathrm{R}$ & A & Foliage & Po \\
\hline & Episomus chinensis Faust & $\mathrm{O}$ & A & Foliage & Unknown \\
\hline & Episomus turritus (Gyllenhal) & $\mathrm{O}$ & A & Foliage & Unknown \\
\hline & Eugnathus sp. & $\mathrm{R}$ & A & Foliage & Unknown \\
\hline & Macrocorynus capito (Faust) & $\mathrm{R}$ & A & Foliage & Po \\
\hline & Macrocorynus plumbeus Formanek & $\mathrm{R}$ & A & Foliage & Po \\
\hline & Ornatalcides (Mesalcidodes) trifidus (Pascoe) & $\mathrm{O}$ & A & Stem, Terminal & Po? \\
\hline \multirow[t]{2}{*}{ Meloidae } & Epicauta obscurocephala Reitter & $\mathrm{C}$ & A & Foliage & Po \\
\hline & Epicauta chinensis Laporte & $\mathrm{C}$ & A & Foliage & Po \\
\hline \multirow[t]{4}{*}{ Scarabaeidae } & Anomala corpulenta Motsch & $\mathrm{R}$ & A & Foliage & Po \\
\hline & Anomala straminea Semenov & $\mathrm{R}$ & A & Foliage & Po \\
\hline & Anomala sulipennis Faldermann & $\mathrm{R}$ & A & Foliage & Po \\
\hline & Popillia mutans Newman & $\mathrm{R}$ & A & Foliage & Po \\
\hline \multicolumn{6}{|l|}{ Hymenoptera } \\
\hline Argidae & Arge sp. & $\mathrm{C}$ & $\mathrm{L}$ & Foliage & Mo? \\
\hline Tanaostigmatidae & Tanaostigmodes puerariae sp.nov. & $\mathrm{C}$ & A & Foliage, Gall & Unknown \\
\hline \multicolumn{6}{|l|}{ Lepidoptera } \\
\hline Amatidae & Amata germana Felder & $\mathrm{R}$ & A & Foliage & Po \\
\hline Hepialidae & Phassus sinifer sinensis Moore & $\mathrm{O}$ & $\mathrm{L}$ & Foliage & Unknown \\
\hline \multirow{3}{*}{ Nymphalidae } & Argyronome ruslana Motschulsky & $\mathrm{R}$ & A & Foliage & Unknown \\
\hline & Pareda vesta $\mathrm{F}$. & $\mathrm{C}$ & A & Foliage & Unknown \\
\hline & Polygonia chaohualbum hemigera Butler & $\mathrm{C}$ & A & Foliage & Unknown \\
\hline Pyralidae & Maruca testulalis Geger & $\mathrm{C}$ & $\mathrm{L}$ & Seed & Po \\
\hline
\end{tabular}


Table 1 (continued)

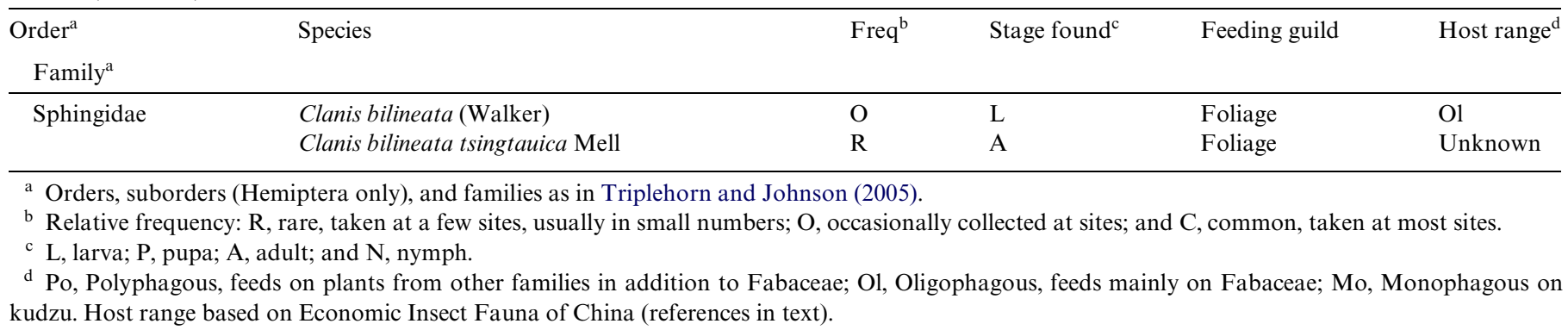

Table 2

Numbers of phytophagous arthropod species in different feeding guilds recorded from kudzu in China and in the US

\begin{tabular}{lcllll}
\hline Feeding guild & \multicolumn{2}{c}{ United States $^{\mathrm{a}}$} & & \multicolumn{2}{l}{$\mathrm{China}^{\mathrm{b}}$} \\
\cline { 2 - 3 } \cline { 5 - 6 } \cline { 5 - 6 } & No. families & No. species & & No. families & No. species \\
\hline Foliage feeders & 13 & N/A & & 15 & 37 \\
Seed feeders & 2 & N/A & & 2 & 3 \\
Sap feeders & 14 & N/A & & 13 & 60 \\
Stem borers & 0 & 0 & & 5 & 14 \\
Terminal feeders & 0 & 0 & & 2 & 3 \\
Root feeders & 0 & 0 & & 1 & 2
\end{tabular}

${ }^{a}$ Data from Thornton (2004). N/A, not available.

b Species found infesting two different plant parts were counted in both guilds.

\subsection{Seed damage}

Seed feeders in China included a bruchine beetle (Chrysomelidae, subfamily Bruchinae) and a pyralid moth species. When insects were excluded during pod formation, seed damage was significantly lower than in the uncaged treatment $\left(\chi^{2}=107.9315 ; \quad P<0.001\right.$; Table 4$)$. From an additional 415 pods that were collected from survey plots, a total of 2408 seeds were examined. Of these, 1197 (49.7\%) contained bruchine larvae, $319(13.2 \%)$ contained insect pupae, and $442(18.4 \%)$ of the seeds were shriveled (not fully developed), leaving only $450(18.7 \%)$ apparently healthy seeds.

\subsection{Diseases}

The most commonly observed disease of kudzu was "imitation rust," caused by Synchytrium minutum $[=S$. puerariae (P. Henning) Miyabe]. In one location in Anhui province, disease severity was intense enough to cause vine mortality. The next most common disease was leafspot. Several leafspot fungi were identified, including Pseudocercospora puerariicola (Yamam.) Deighton (angular leafspot), Cercospora puerario-thomsona Chen \& Chi (brown spot), Phomopsis sp., Colletotrichum lindemuthianum, and Colletotrichum sp. (anthracnose).

\section{Discussion}

Insect surveys on kudzu in China revealed a rich phytophagous insect fauna, with 116 species recorded, in six
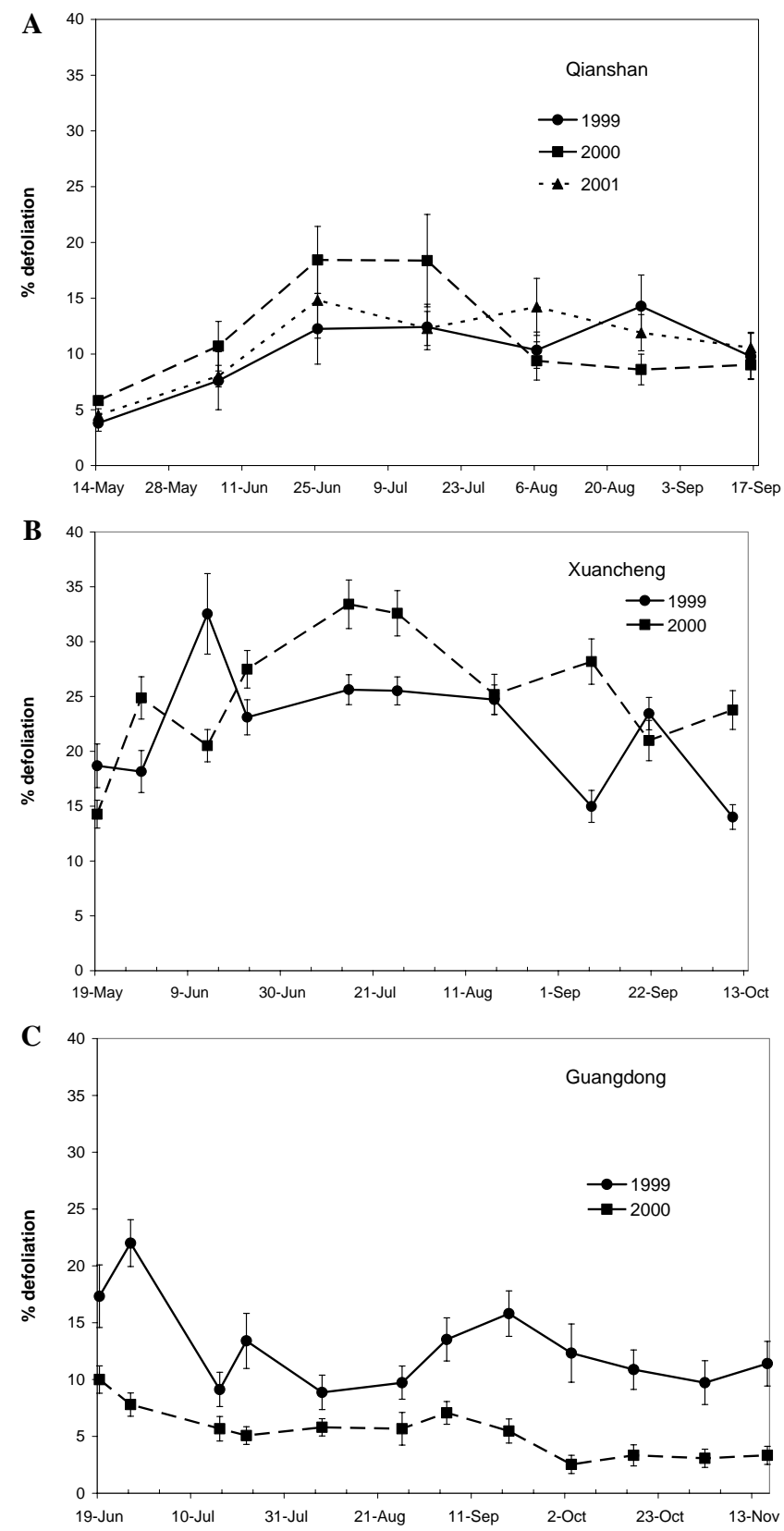

Fig. 1. Kudzu defoliation in (A). Qianshan, 1999-2001; (B) Xuancheng, 1999 and 2000; and (C) Guangdong Province, 1999 and 2000. Means \pm SEM are shown.

insect guilds attacking different parts of kudzu. In the US insects in only three insect guilds are known to infest kudzu (Thornton, 2004). 


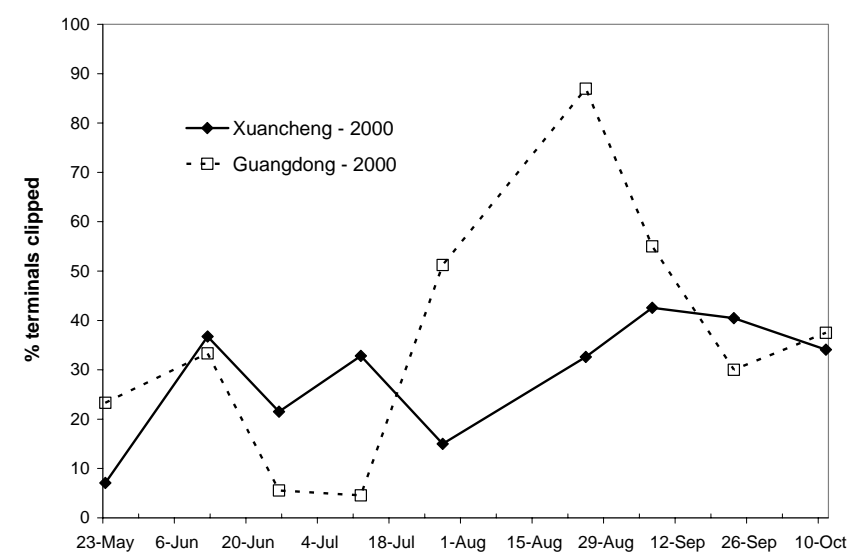

Fig. 2. Percent of kudzu shoots with terminals clipped (primarily by two beetle species, Ornatalcides (Mesalcidodes) [Curculionidae] and Deporaus sp. [Attelabidae]), Xuencheng and Guangdong Province, 2000.

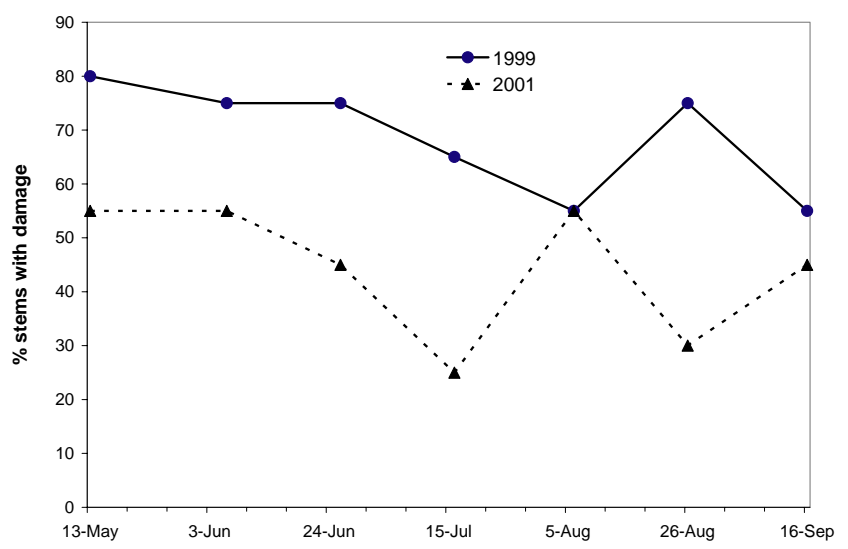

Fig. 3. Percent of kudzu stems with damage (primarily by stem-boring or phloem-feeding Cerambycidae and Buprestidae), Qianshan, 1999 and 2001.

A total of 37 foliage-feeding insect species from 15 families were found on kudzu in China, with two chrysomelids and a sawfly apparently causing the most extensive defoliation. Thornton (2004) reported that all leaf-feeding species on kudzu in the US were generalist herbivores. In China, although most of the species were generalists, we found several species primarily or solely infesting leaves of kudzu.

In the US, no terminal feeders or stem borers have been observed (Thornton, 2004), while in China many insects attack kudzu terminals and stems. The damage caused by these insects can be severe, with up to $90 \%$ of new terminals clipped and $50-80 \%$ of stems damaged at some sites.

No root-infesting insects have been found on kudzu in the US, while in China roots were heavily damaged by cerambycid beetles. In China, these insects infest about 50\% of roots, and were found to attack both small (young) and large (old) roots, with even large roots severely damaged. In our samples from Qianshan, small and large roots were more likely to be attacked than intermediate sized roots. Further study is needed to determine whether this reflected damage by two different species, or by two different instars of the same species.

Kudzu seeds were also heavily damaged by insects in China, with about $70 \%$ of seeds caused to be nonviable. Insects attacking seeds included a pyralid moth and a bruchine (chrysomelid) beetle. Kidd (2002) also found heavy damage to uncaged kudzu seed in North Carolina, with only $19 \%$ of non-caged seeds free of insect damage compared with $91 \%$ of caged seeds. Seed damage in her study was attributed to several generalist hemipterans and a naturalized bruchine of Asian origin, Borowiecius ademptus (Sharp). Similar results were reported by Thornton (2004).

"Imitation rust" was the most common disease observed on kudzu in China. This disease has only been reported on P. montana var. lobata and P. thomsonii (Feng et al., 1999; Tai, 1979). The causal pathogen $S$. minutum was described as Uredo minuta by Saccardo in 1893, probably because the brilliant orange sori look like rust pustules. Kusano recognized the fungus as a chytrid in 1902, and described the life cycle and host/parasite relationship (Karling, 1964). This fungus attacks leaves, stems, flowers, and seedpods of kudzu, causing erumpent golden sori of unicellular, flagellate zoospores. Severe infection causes leaf distortion and necrosis and rough and swollen stems, with significant occlusion of the vascular tissue.

Table 3

Relationship between kudzu root diameter and insect attack

\begin{tabular}{|c|c|c|c|c|}
\hline Root types & $N$ & Root diameter $(\mathrm{cm})$ & Tunnel diameter $(\mathrm{cm})$ & \\
\hline \multicolumn{5}{|c|}{ (A) Qianshan, Anhui Province } \\
\hline Insect-infested (large) & 11 & $6.7 \pm 0.6 \mathrm{a}$ & $1.6 \pm 0.08 \mathrm{a}$ & \\
\hline Healthy (uninfested) & 121 & $4.7 \pm 0.1 \mathrm{~b}$ & & \\
\hline Insect-infested (small) & 42 & $3.3 \pm 0.1 \mathrm{c}$ & $1.3 \pm 0.03 \mathrm{~b}$ & \\
\hline$F$ & & 32.221 & 19.094 & \\
\hline \multirow[t]{3}{*}{$P$} & & $<0.001$ & $<0.001$ & \\
\hline & & \multicolumn{3}{|l|}{ Root diameter $(\mathrm{cm})$} \\
\hline & & Base & Center & Terminal \\
\hline \multicolumn{5}{|l|}{ (B) Guangdong Province } \\
\hline Healthy (uninfested) & 16 & $2.1 \pm 0.5 \mathrm{a}$ & $3.2 \pm 0.9 \mathrm{a}$ & $1.5 \pm 0.4 \mathrm{a}$ \\
\hline Infested & 25 & $1.6 \pm 0.2 \mathrm{a}$ & $2.6 \pm 0.4 \mathrm{a}$ & $1.4 \pm 0.2 \mathrm{a}$ \\
\hline$F$ & & 1.242 & 0.584 & 0.086 \\
\hline$P$ & & 0.271 & 0.449 & 0.771 \\
\hline
\end{tabular}

Data shown as means \pm SEM. Means followed by different letters in each column are significantly different $(P<0.05$, Scheffe's test $)$. 
Table 4

Effects of insects on seed damage in Qianshan, Anhui Province

\begin{tabular}{ll}
\hline Treatment & $\%$ of damaged seeds \\
\hline Control (uncaged) & 64.7 \\
Insects excluded (caged) & 36.3 \\
$P$ & $<0.001$ \\
\hline
\end{tabular}

$N=1429$ seeds from uncaged and 424 seeds from caged treatments. Data analyzed using $\chi^{2}$ analysis.

From an ecological perspective, it seems likely that the abundant and diverse insect fauna along with the various pathogens that we observed on kudzu constitute an important check on the growth and spread of kudzu in China, while the relatively sparse fauna in the US contributes to its invasive habit and pest status there. From a biological control perspective, defoliators, terminal or stem feeders, and root-infesting species should all be considered as potential control agents. Seed feeders should not be considered, because kudzu in the US already experiences high levels of seed destruction, and because most spread of kudzu in the US is vegetative.

The most important hurdle for any potential biological control agent to cross before it can be imported into the US will be demonstration of sufficient host specificity. Although no Pueraria species other than kudzu are present on the continental US, there are several species in different genera in the same subtribe (Glycininae) as kudzu, with the introduced crop species Glycine max (L.) Merr. (soybean) of greatest economic importance. Many other economically and ecologically important plants occur within the same family (Fabaceae $=$ Leguminoseae) as kudzu. A proposed test list was submitted to the Technical Advisory Group for Biological Control of Weeds (TAG) in 2004 (Birdsall and Hough-Goldstein, 2004), detailing the breadth of plant taxa that must be tested before a potential agent can be approved for release.

The imitation rust fungus that we recovered shows potential as a biological control agent, but much work remains to establish its host specificity. The first step in this process will be the development of an artificial inoculation technique on kudzu. Among the insect species that we collected on kudzu, several are thought to be monophagous or oligophagous based on observations and on Chinese taxonomic references, and therefore will be tested either in China or in quarantine in the US. Following are the most promising species identified to date.

Gonioctena tredecimmaculata (Jacoby) (Coleoptera: Chrysomelidae) is a voracious consumer of kudzu foliage, both as adults and as larvae, and is currently being studied in quarantine in Newark, DE, USA. In a recent taxonomic review, Bezděk (2002) concluded that the species usually identified as $G$. tredecimmaculata is actually made up of five independent species. Based both on distribution (eastern China, not Sichuan) and morphology, the species under study is the true G. tredecimmaculata. Host plants for the Gonioctena group have been reported as Mucuna sp. and $P$. montana by Russian authors, but have not been reported specifically for the Chinese species (Bezděk, personal communication, 2004).

The sawfly, Arge sp. (Hymenoptera: Argidae), which is also a defoliator, and the leafroller weevil, Deporaus sp. (Coleoptera: Attelabidae), a terminal clipper, must be identified to species before they can be fully evaluated. Preliminary host-range tests in China indicate potential monophagy.

Ornatalcides (Meslcidodes) trifidus (Pascoe) (Coleoptera: Curculionidae), a terminal clipper and gall-forming weevil, reportedly feeds on Lespedeza spp. (Zheng et al., 2004) in addition to kudzu, but this needs to be confirmed. In preliminary tests in China, this weevil fed on soybean as adults but did not complete its life cycle on soybean.

Finally, P. diophthalma (Pascoe) (Coleoptera: Cerambycidae) was found infesting kudzu stems and roots in this study, causing severe damage. There appears to be no available literature on its host specificity, and host specificity trials have not yet been conducted.

\section{Acknowledgments}

We are grateful to Dr. Yang Zhongqi, Dr. Jiang Zide, Dr. Tian Mingyi, Mr. Li Jianfeng, and Mr. Ma Shenan for assistance with the field survey. This research is part of an ongoing Sino-US kudzu biological control cooperative program funded by the Forest Health Enterprise Team, International Forestry Programs, and the Southern Research Station of the USDA-Forest Service. The publication of this paper is partially supported by the CAS Key Innovation Project (KSCX1-Sw-13).

\section{References}

Alderman, D.H., 1998. A vine for postmodern times: an update on kudzu at the close of the twentieth century. Southeast Geogr. 38, 167-179.

An, L.L., Liu, L.C., Li, X.X., 1994. A promising plant for commercial utilization-kudzu. Changjiang Vegetable 5, 1-4 (in Chinese).

Bezděk, J., 2002. A review of the Gonioctena tredecimmaculata (Jacoby, 1888) group (Coleoptera, Chrysomelidae, Chrysomelinae). Entomol. Basiliensia 24, 7-22.

Birdsall, J., Hough-Goldstein, J., 2004. Proposed host specificity plant list for testing potential biological control agents of kudzu. TAG Petition 04-05, submitted to the Technical Advisory Group for Biological Control Agents of Weeds, USDA, APHIS, PPQ, Riverdale, MD, USA.

Bonsi, C., Rhoden, E., Woldeghebriel, A., Mount, P., Solaiman, S., Noble, R., Paris, G., McMahon, C., Pearson, H., Cash, B., 1992. Kudzu-goat interactions - a pilot study. In: Solaiman, S.G., Hill, W.A. (Eds.), Using Goats to Manage Forest Vegetation, a Regional Inquiry. Tuskegee Univ. Agric. Exp. Sta., Tuskegee, AL, pp. 84-88.

Britton, K.O., Orr, D., Sun, J.H., 2002. Kudzu. In: Van Driesche, R. (Ed.), Biological Control of Invasive Plants in the Eastern United States. USDA Forest Service Publication FHTET-2002-04. < http://www.invasive.org/eastern/biocontrol/25Kudzu.html>.

Chen, M.H., Zhang, S.J., 1985. Chemical components of kudzu root. Bull. Tradit. Chin. Med. 10, 35-36 (in Chinese).

Corley, R.N., Woldeghbriel, A., Murphy, M.R., 1997. Evaluation of the nutritive value of kudzu (Pueraria lobata) as a feed for ruminants. Animal Feed Sci. Tech. 68, 183-188.

Duke, J.A., 1981. Handbook of Legumes of World Economic Importance. Plenum Press, New York. 
Ensminger, M.E., Olentine Jr., C.G., 1978. Feeds and Nutrition-Complete. The Ensminger Publishing, Clovis, CA. p p. 1246-1247.

Everest, J.W., Miller, J.H., Ball, D.M., Patterson, M., 1999. Kudzu in Alabama: History, Uses, and Control. ANR-65. Alabama Cooperative Extension, Auburn, AL. 6 .

Fears, R.D., Frederick, D.M., 1977. Kudzu control on forest planting sites. Proc. Southern Weed Sci. Soc. 30, 260.

Feng, Y., Huang, L., Chen, J., 1999. Pathogenic identification of the imitation rust of Pueraria thomsonii in Guangzhou area. Plant Prot. 25, 11-13 (in Chinese).

Forseth, I.N., Innis, A.F., 2004. Kudzu (Pueraria montana): history, physiology, and ecology combine to make a major ecosystem threat. Crit. Rev. Plant Sci. 23, 401-413.

Forseth, I.N., Teramura, A.H., 1987. Field photosynthesis, microclimate and water relations of an exotic temperate liana, Pueraria lobata, kudzu. Oecologia 71, 262-267.

Frankel, E., 1989. Distribution of Pueraria lobata in and around New York City. Bull. Torrey Botan. Club 116, 390-394.

Ge, Z.L., 1966. Fasc. 10 Homoptera: Cicadellidae. Economic Insect Fauna of China (Editorial Committee of Fauna Sinica, Academia Sinica, eds.), Science Press, Beijing, China (in Chinese).

Ge, Z.L., Ding, J.H., Tian, L.X., Huang, Q.L. 1984. Fasc. 27 Homoptera: Delphacidae. Economic Insect Fauna of China (Editorial Committee of Fauna Sinica, Academia Sinica, eds.), Science Press, Beijing, China (in Chinese).

Harrington, T.B., Rader-Dixon, L.T., Taylor Jr., J.W., 2003. Kudzu (Pueraria montana) community responses to herbicides, burning, and highdensity loblolly pine. Weed Sci. 51, 965-974.

Holm, L.G., Pancho, J.V., Herberger, J.P., Plucknett, D.L., 1979. A Geographical Atlas of World Weeds. John Wiley \& Sons, New York. p. 25.

Jinag, S.N., Pu, F.J., Hua, L.Z. 1985. Fasc. 35 Coleoptera: Cerambycidae (III). Economic Insect Fauna of China (Editorial Committee of Fauna Sinica, Academia Sinica, eds.), Science Press, Beijing, China (in Chinese).

Karling, J.S., 1964. Synchytrium. Academic Press, NY. 470.

Keung, W.M., Vallee, B.L., 1998. Kudzu root: an ancient Chinese source of modern antidipsotropic agents. Phytochemistry 47, 499-506.

Kidd, K.A., 2002. Interaction of kudzu, Pueraria montana (Lour.) Merr. var. lobata (Willd.), and arthropods in North Carolina. PhD dissertation, North Carolina State University, Raleigh, NC.

Liu, C.L. 1963. Fasc. 5 Coleoptera: Coccinellidae. Economic Insect Fauna of China (Editorial Committee of Fauna Sinica, Academia Sinica, eds.), Science Press, Beijing, China (in Chinese).

Liu, Y.Q., Bai, J.W. 1977. Fasc.11 Lepidoptera: Totricoidae. Economic Insect Fauna of China (Editorial Committee of Fauna Sinica, Academia Sinica, eds.), Science Press, Beijing, China (in Chinese).

Matlack, G.R., 2002. Exotic plant species in Mississippi, USA: critical issues in management and research. Nat. Areas J. 22, 241-247.

Miller, J.H., 1996. Kudzu eradication and management. In: Hoots, D., Baldwin, J. (Eds.), Kudzu: the Vine to Love or Hate. Suntop Press, Kodak, TN, pp. 137-149.

Miller, J.H., Edwards, B., 1983. Kudzu: where did it come from? And how can we stop it? South. J. Appl. For. 7, 165-169.

Mississippi State University, 2001. Effective kudzu control. MSU Extension Service. $<$ http://msucares.com/forestry/management/kudzu.html $>$.

Mitich, L.W., 2000. Intriguing world of weeds: kudzu [Pueraria lobata (Willd.) Ohwi]. Weed Technol. 14, 231-234.

Patterson, D.T., 1976. The history and distribution of five exotic weeds in North Carolina. USA Castanea 41, 177-180.

Pemberton, R.W., 1996. The potential of biological control for the suppression of invasive weeds of southern environments. Castanea 61, 313-319.

Piper, C.V., 1920. Kudzu. USDA Department Circular 89. 7.

Pu, F.J. 1980. Fasc.19 Coleoptera: Cerambycidae (II). Economic Insect Fauna of China (Editorial Committee of Fauna Sinica, Academia Sinica, eds.), Science Press, Beijing, China (in Chinese).

SAS Institute 1998. The SAS System for Windows. SAS Institute, Cary, NC.

Shao, X.Q., 1993. Potential of wild kudzu for utilization. Q. Forest ByProduct Spec. China 4 (27), 42-43 (in Chinese).

SPSS Inc., 1999. The Basics: SPSS for Windows 10.0. SPSS Inc. Chicago, IL.

Tabor, P., Susott, A.W., 1941. Zero to thirty million mile-a-minute seedlings. Soil Cons. 7, 61-65.
Tai, F.L., 1979. Sylloge Fungorum Sinicorum. Science Press, Beijing, China. 5 8. (in Chinese).

Tan, J.J., Yu, P.Y., Li, H.X., Wang, S.Y. 1985. Fasc.18 Coleoptera: Chrysomeloidae (I). Economic Insect Fauna of China (Editorial Committee of Fauna Sinica, Academia Sinica, eds.), Science Press, Beijing, China (in Chinese).

Tanner, R.D., Hussain, S.S., Hamilton, L.A., Wolf, F.T., 1979. Kudzu (Pueraria lobata): potential agricultural and industrial resource. Econ. Bot. $33,400-412$.

Tayutivutikul, J., Kusigemati, K., 1992. Biological studies of insects feeding on the kudzu plant, Pueraria lobata (Leguminosae) 1. List of feeding species. Mem. Fac. Agr. Kagoshima Univ. 28, 89-124.

Tayutivutikul, J., Yano, K., 1989. Biology of insects associated with the kudzu plant, Pueraria lobata (Leguminosae) 1. Chauliops fallax (Hemiptera, Lygaeidae). Jpn. J. Entomol. 57, 831-842.

Tayutivutikul, J., Yano, K., 1990. Biology of insects associated with the kudzu plant, Pueraria lobata (Leguminosae) 2. Megacopta punctissimum (Hemiptera, Plataspidae). Jpn. J. Entomol. 58, 533-539.

Thomas Jr., L.K., 2000. Chemical grubbing for control of exotic kudzuvine. Bartonia 60, 71-74.

Thornton, M.R., 2004. Arthropod fauna associated with kudzu ( Pueraria lobata Willd.) in North Carolina. M.S. thesis, North Carolina State University, Raleigh, NC.

Triplehorn, C.A., Johnson, N.F., 2005. Borrer and DeLong's Introduction to the Study of Insects, seventh ed. Thompson Brooks/Cole, Belmont, CA.

Ward, D.B., 1998a. Pueraria montana: the correct scientific name of the kudzu. Castanea 63, 76-77.

Ward, D.B., 1998b. A varietal correction in Pueraria montana (Leguminosae). Phytologia 84, 385-388.

Washington State Noxious Weed Control Board, 2003. Written findings of the state noxious weed control board, kudzu. <http:// www.nwcb.wa.gov/weed_info/Kudzu.html>.

Winberry, J.J., Jones, D.M., 1973. Rise and decline of the 'miracle vine': kudzu in the southern landscape. Southeast Geog. 13, 63-67.

Yang, J.H., Wu, S.Z., Wang, B., 1990. The research of soil erosion control of kudzu. Shandong Forest Science 77, 37-40 ( in Chinese).

Yang, X.C., Wan, X.C., Wang, P., Li, C., Lu, C.Z., 1996. A study on kudzu utilization and its prospect. Forest Sci. Technol. 1, 16-17 (in Chinese).

Yu, P.Y., Wang, S.Y., Yang, X.K. 1996. Fasc. 54 Coleoptera: Chrysomeloidae (II). Economic Insect Fauna of China (Editorial Committee of Fauna Sinica, Academia Sinica, eds.), Science Press, Beijing, China (in Chinese)

Zhang, C.O., Wang, X.H., 1999. The research and utilization of kudzu (Pueraria lobata). Shaanxi Forest Sci. Technol. 1, 24-26 (in Chinese).

Zhang, C.Q., 1987. An experimental study on kudzu. Grass Sci. China 4 (5), 36-40 (in Chinese).

Zhang, C.Q., Gu, M., 1998. Kudzu, the potential forage plant in Guizhou. Guizhou Agric. Sci. 26 (4), 9-12 (in Chinese).

Zhang, C.Q., Ye, M.L., 1990. A good forage in Guanzhou: its cultivation and utilization of kudzu. Guizhou Agric. Sci. 3, 63-65 ( in Chinese).

Zhang, S.M. 1985. Fasc. 31 Hemiptera (1). Economic Insect Fauna of China (Editorial Committee of Fauna Sinica, Academia Sinica, eds.), Science Press, Beijing, China (in Chinese).

Zhang, S.M. 1995. Fasc. 50 Hemiptera (2). Economic Insect Fauna of China (Editorial Committee of Fauna Sinica, Academia Sinica, eds.), Science Press, Beijing, China (in Chinese).

Zhao, Y.C., Chen, Y.Q. 1980. Fasc. 20 Coleoptera: Curculionidae (I). Economic Insect Fauna of China (Editorial Committee of Fauna Sinica, Academia Sinica, eds.), Science Press, Beijing, China (in Chinese).

Zheng, H., Wu, Y., Ding, J., Binion, D., Fu, W., Reardon, R., 2004. Invasive plants of Asian origin established in the United States and their natural enemies. vol. 1. USDA Forest Service, FHTET 200405.

Zhu, W.X., 1996. Kudzu, the potential forage plant in Mountain Dabieshan. Grassland China 6, 6 ( in Chinese).

Zidak, N.K., Backman, P.A., 1996. Biological control of kudzu (Pueraria lobata) with the plant pathogen Pseudomonas syringae pv. phaseolicola. Weed Sci. 44, 645-649. 